\title{
Characterization of anti-plasmodial, analgesic and anti-inflammatory fraction of Maytenus senegalensis (lam.) Exell leaf extract in mice
}

\author{
Ali A. Jigam ${ }^{1}$, Rachael Musa ${ }^{1}$, Abdulkadir Abdullahii ${ }^{1}$ and Bashir Lawal ${ }^{1,2^{*}}$ (D)
}

\begin{abstract}
Background: The treatment inadequacy and toxicity associated with conventional anti-malarial, anti-inflammatory and analgesic drugs has called for the search of alternatives from medicinal plants, particularly, their phytochemicals with inherent pharmacological properties. In the present study, purified fraction of M. senegalensis leaf was evaluated for antimalarial, anti-inflammatory and analgesic properties.

Method: Antimalarial study was conducted against Plasmodium chabaudi and Plasmodium berghei using 4 days suppressive test, while anti-inflammatory and analgesic studies were conducted using egg albumin induced paw oedema and acetic acid induced pain model respectively. Sub-acute toxicity was assessed using serum biochemical parameters following 3 weeks administrations of the purified fraction.

Results: The purified fraction of $M$. senegalensis leaf shows dose dependent antiplasmodial activity with percentage curative effects of $15.24 \pm 0.89,45.70 \pm 3.43$ and $48.50 \pm 4.56$ at 75,150 and $300 \mathrm{mg} / \mathrm{kg}$ bw against Plasmodium chabaudi and \% curative effects of $44.25 \pm 3.21,72.74 \pm 6.54$ and $76.30 \pm 8.32$ respectively against Plasmodium berghei. The purified fraction exhibited $53.16 \pm 4.09$ and $60.76 \pm 7.54$ anti-inflammatory effect, $43.35 \pm 4.98 \%$ and $44.83 \pm 3.86 \%$ analgesic effect at 75 and $150 \mathrm{mg} / \mathrm{kg}$ bw respectively. GC-MS analysis confirmed the presence of 20a)-3-hydroxy-2-oxo-24-nor-friedela-1(10),3,5,7-tetraen-carboxylic acid-(29)-methylester, 2(4H)-Benzofuranone, 5,6,7, 7a-tetrahydro- and 3-hydroxy-20(29)-lupen-28-ol and a terpenes (phytol) as the major antimalarial compounds in the fraction. The purified fraction increases the serum total proteins and transaminases concentrations but had no effect on serum levels of sodium, potassium, chloride, alkaline phosphatase, triglyceride and glucose in the mice. Conclusion: The purified fraction of $M$. senegalensis leaf exhibited promising antimalarial, analgesic and antiinflammatory activities. Thus, could serve as a template for the synthesis of new drug.
\end{abstract}

Keywords: Anti-plasmodial, Anti-inflammatory, Analgesic, Maytenus senegalensis (lam.) Exell

\footnotetext{
* Correspondence: lawal.b@st.futminna.edu.ng

'Department of Biochemistry, Federal University of Technology, Minna,

Nigeria

${ }^{2}$ Program for Cancer Molecular Biology and Drug Discovery, Taipei Medical

University and Academia Sinica, Taipei 111, Taiwan
}

\section{Springer Open}

(c) The Author(s). 2020 Open Access This article is licensed under a Creative Commons Attribution 4.0 International License, which permits use, sharing, adaptation, distribution and reproduction in any medium or format, as long as you give appropriate credit to the original author(s) and the source, provide a link to the Creative Commons licence, and indicate if changes were made. The images or other third party material in this article are included in the article's Creative Commons licence, unless indicated otherwise in a credit line to the material. If material is not included in the article's Creative Commons licence and your intended use is not permitted by statutory regulation or exceeds the permitted use, you will need to obtain permission directly from the copyright holder. To view a copy of this licence, visit http://creativecommons.org/licenses/by/4.0/. 


\section{Introduction}

Malaria is an infectious protozoic and parasitic disease caused by five Plasmodium parasites: vivax, falciparum, malariae, Knowlesi and ovale [1]. More than half of the world's population are at risk of malaria, with about 212 million new case and 429, 000 death annually [2]. SubSaharan Africa accounts for over $90 \%$ of the malaria cases and deaths predominantly in children of age below five years and pregnant women [2]. Poor rural dwellers in in tropical and subtropical areas are highly vulnerable to this attacked owing to the favorable and ideal climatic condition for the reproduction and development of vectors, and parasites [3]. In addition, drug resistance is one of the major challenges facing malarial eradication program word wide [4].

Inflammation and pains are gaining research popularity owing to the etiologic role they play in various human diseases [5]. Dexamethasone, opioids, morphine and aspirin and other drugs have been established for the management of pain and inflammation; however, these drugs have recorded limited success due to unintended effects such as gastric lesions caused by nonsteroidal anti-inflammatory drugs $[6,7]$. Thus, the search for drugs alternative from natural product is recommended.

Natural products contain metabolite that has therapeutic values for uses in the managements of several diseases $[8,9]$. The therapeutic effect plants are however, associated with their secondary metabolites they contain, particularly the alkaloids, terpenoids, and flavonoids, which are known to play defensive role in plants but exihibited different pharmacological effects in human/ animals [10].

Maytenus senegalensis (Lam.) Exell is an African medicinal plant, commonly used traditionally for the treatment of a number of ailments, including rheumatism, snakebites, diarrhoea, eye infection, and dyspepsia [11]. Previous study has demonstrated that the extracts from various parts of $M$. senegalensis possess in vitro antiplasmodial, anti-leishmanial, and antibacterial activities [12]. However, literature survey revealed dearth of scientific information on the pharmacological activities of purified fraction. The present study, therefore evaluated the antiplasmodial analgesic and anti-inflammatory effects of purified fractions from Maytenus senegalensis (Lam.) Exell leaf extract in mice.

\section{Materials and methods}

\section{Experimental animals}

A total of ninety (90) adult swiss albino mice weighing $25.34 \pm 0.98 \mathrm{~g}$ were obtained from National Veterinary Research Institute (NVRI), Vom, Plateau State of Nigeria. The mice handling and experimentation was in concordance with the guidelines for laboratory animal use and care as contained in the European Convention on Animal Care Guidelines and Protocol.

\section{Parasite \\ Plasmodium chabaudi and Plasmodium berghei NK65 chloroquine-sensitive strain was obtained from National Institute of Pharmaceutical Research and Development (NIPRD) Abuja, Nigeria and maintained in the labora- tory by serial passage in mice.}

\section{Sample preparation}

The plant Maytenus senegalensis (Lam.) Exell was collected from Bida, Niger state. The plant was authenticated by a botanist, from Department of Biological sciences, Federal university of Technology Minna, Nigeria. The leave was cleaned and air-dried at room temperature. The dried leave was pulverized into a coarse powder using mortar and pestle. The pulverized sample was stored in air-tight container.

\section{Extraction and purification of Maytenus senegalensis} (lam.) Exell fraction

Maytenus senegalensis (Lam.) Exell leaf (50 g) powder was moistened with $200 \mathrm{~mL}$ of $95 \%$ ethanol, alkalinified with $200 \mathrm{~mL}$ of ammonia solution and macerated for 24 $\mathrm{h}$ followed by extraction with ethanol. The ethanol extract was filtered, concentrated and treated with $1.0 \mathrm{~N}$ hydrochloric acid. The filtrate was further alkalinified with ammonia solution and the extract was obtained by fractionation in separating funnel using chloroform [13]. The fraction was purified and subjected to thin layer chromatography to obtained the pure fraction $(0.6 \mathrm{~g})$ for structural elucidation [13].

\section{Anti-Plasmodial screening of the purified fraction of Maytenus senegalensis (lam.) Exell}

Four days (4) suppressive test were used to evaluate the antimalarial properties of the purified fraction of Maytenus senegalensis (Lam.) Exell as described by Jigam et al. [14]. A total of 15 P. berghei infected mice were randomly grouped into five (I- V) of 3 mice each. Groups I - III animals were treated with 75, 150 and $300 \mathrm{mg} / \mathrm{kg}$ body weight each of purified fraction. Groups IV and V received normal saline $(2 \mathrm{ml} / \mathrm{kg}$ body weight) and chloroquine ( $5 \mathrm{mg} / \mathrm{kg}$ body weight) to serve as negative and positive controls respectively. The same procedures (Four days (4) suppressive test) were repeated for Plasmodium chabaudi All the treatments were done orally for 4 consecutive days. Daily parasitaemia count was carried out by preparing a Giemsa stained-thin film and viewed under microscope as described by Jigam et al. [14]. 
$\%$ inhibition $=\frac{\text { Mean parasitemia in negative control }- \text { Mean parasitemia in treated }}{\text { Mean parasitemia in negative control }}$ $\times 100$

\section{Anti-inflammatory study}

Anti-inflammatory activity of the purified fraction was tested using egg albumin induced paw oedema in mice according to the methods of Winter et al. [15]. A total of twelve (12) mice were randomly grouped into four (A- D) of 3 mice each and were administered a single dose of 75 and $150 \mathrm{mg} / \mathrm{kg}$ bw of the purified fraction, $150 \mathrm{mg} / \mathrm{kg}$.bw acetylsalicylic acid and $2 \mathrm{ml} / \mathrm{kg}$ bw normal saline respectively $30 \mathrm{~min}$ before the injection of the albumin into the right hind limb. The percentage inhibition of oedema was calculated for each dose using the formula:

\%inhibition $=\frac{\text { Mean increase in paw in negative control }- \text { Mean increase in paw in treated }}{\text { Mean increase in paw in negative control }}$ $\times 100$

\section{Analgesic study}

Analgesic effect was assessed according to the method described by Nwafor et al. [16]. A total of twelve (12) mice were randomly grouped into four (A-D) of 3 mice each and were administered a single dose of 75 and 150 $\mathrm{mg} / \mathrm{kg}$ bw of the purified fraction, $150 \mathrm{mg} / \mathrm{kg}$.bw sodium diclofenac and $2 \mathrm{ml} / \mathrm{kg}$ bw normal saline respectively for $60 \mathrm{~min}$ before they were challenged with $0.75 \% \mathrm{v} / \mathrm{v}$ acetic acid. Group D (control group) received $2 \mathrm{~mL} / \mathrm{kg}$ body weight of normal saline. The number of abdominal constrictions induced by acetic acid were counted after 5 min. Observations were made over $10 \mathrm{~min}$ and mean value for each group was calculated. Percentage inhibition of abdominal constriction by the purified fraction and sodium diclofenac were determined in relation to the control.

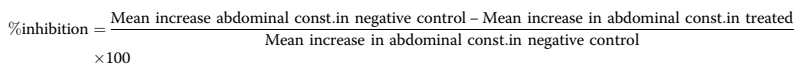

\section{Toxicological study}

Animals (5 each) were dosed 0 (control), $75 \mathrm{mg} / \mathrm{kg}$ and $150 \mathrm{mg} / \mathrm{kg}$ bwt of purified fraction of Maytenus senegalensis (Lam.) Exell orally for 3 wks. Procedures described by Shittu et al. [17] was followed during blood sample collection and serum preparation for biochemical analysis. Serum biochemical parameters including alkaline phosphatase (ALP), Aspartate transaminase (AST) and alanine transaminase (ALT) were determined as described previously [18]. The concentrations of serum total proteins [19], sodium, potassium, and chloride [20] were determine using standard methods.
Gas chromatography and mass spectroscopy (GC-MS) analysis of bioactive compounds

The purified fraction of Maytenus senegalensis (Lam.) Exell was subjected to Gas Chromatography and Mass Spectroscopy for the determination of bioactive volatile compounds as described previously [21].

\section{Data analysis}

Data analysis was performed using Statistical Package for Social Sciences (SPSS) One-way Analysis of Variance (ANOVA) followed by Duncan Multiple Range Test (DMRT). Data were expressed as means \pm SEM of triplicate determinations. Significant was considered at $p<0.05$.

\section{Results \\ Antiplasmodial}

The purified fraction of $M$. senegalensis leaf shows dose dependent antiplasmodial activity against Plasmodium chabaudi (Table 1) and Plasmodium berghei (Table 2). The purified fraction had curative effects of $15.24 \pm$ $0.89 \%, 45.70 \pm 3.43 \%$ and $48.50 \pm 4.56 \%$ at 75,150 and $300 \mathrm{mg} / \mathrm{kg}$ bw against Plasmodium chabaudi (Table 1) while curative effects of $44.25 \pm 3.21 \%, 72.74 \pm 6.54 \%$ and $76.30 \pm 8.32 \%$ respectively against Plasmodium berghei (Table 2).

\section{Anti-inflammatory}

The purified fraction of $M$. senegalensis leaf exhibited dose dependent inhibition egg albumin-induced paw oedema with percentage inhibition of $53.16 \pm 4.09$ and $60.76 \pm 7.54$ at 75 and $150 \mathrm{mg} / \mathrm{kg}$ bw respectively while ASA exhibited $63.29 \pm 5.98$ inhibition of paw oedema (Table 3).

\section{Analgesic effect}

The purified fraction of M. senegalensis leaf exhibited dose dependent abdominal constrictions with percentage inhibition of $43.35 \pm 4.98$ and $44.83 \pm 3.86$ at 75 and $150 \mathrm{mg} / \mathrm{kg}$ bw respectively while sodium diclofenac (SD) exhibited $74.88 \pm 6.87$ inhibition of paw oedema (Table 4 ).

\section{Biochemical parameters}

Sub-chronic administration of the purified fraction of $M$. senegalensis significantly $(p<0.05)$ increase the concentrations of transaminases (aspartate transaminase and alanine transaminase), and proteins when compared with the untreated control. However, sodium, potassium, chloride, alkaline phosphatase, triglyceride and glucose concentrations were not $(\mathrm{p}<$ 0.05 ) significantly altered by treatment with purified fraction of $M$. senegalensis (Table 5). 
Table 1 Antiplasmodial activity of purified fraction of $M$ senegalensis leaf against Plasmodium chabaudi Infected mice

\begin{tabular}{llllllllll}
\hline & Doses $(\mathrm{mg} / \mathrm{kg}$ bw) & 1 & 2 & 3 & 4 & 5 & 6 & Mean Parasitaemia & \% suppression \\
\hline MS & 75 & 130.56 & 120.87 & 134.09 & 100.05 & 88.06 & 79.67 & $108.98 \pm 6.83$ & $15.24 \pm 0.89^{\mathrm{a}}$ \\
& 150 & 79.05 & 86.55 & 80.05 & 58.03 & 60.43 & 54.08 & $69.53 \pm 3.45$ & $45.70 \pm 3.43^{\mathrm{b}}$ \\
& 300 & 80.04 & 84.35 & 70.55 & 60.55 & 49.55 & 56.56 & $66.54 \pm 5.98$ & $48.50 \pm 4.56^{\mathrm{b}}$ \\
CQ & 5 & 36.05 & 42.05 & 58.05 & 40.50 & 22.55 & 18.05 & $21.55 \pm 2.35$ & $83.50 \pm 8.89^{\mathrm{c}}$ \\
NS & $2 \mathrm{ml} / \mathrm{kg}$ & 136.05 & 140.55 & 150.46 & 122.05 & 102.05 & 118.55 & $128.05 \pm 9.89$ & \\
\hline
\end{tabular}

Data are MEAN \pm SEM of triplicate determinations. Values followed by different superscript are significantly different $(p<0.05)$ MS: Maytenus senegalensis (Lam.) Exell CQ: Chloroquine

NS: Normal saline.

\section{GC-MS of the purified fraction of Maytenus senegalensis (lam.) Exell}

The results pertaining to gas chromatography and mass spectroscopy (GC-MS) analysis led to the identification of 13 compounds from the gas chromatography (GC) fractionations. The chromatogram of purified fraction of Maytenus senegalensis (Lam.) Exell is shown in Fig. 1. The results were tabulated in Table 6 . The results revealed that the presence of 3-hydroxy-20(29)-lupen-28ol (12.95\%), 20 $\alpha$ )-3-hydroxy-2-oxo-24-nor-friedela-1(10), 3,5,7-tetraen-carboxylic acid-(29)-methylester (6.0\%), 2(4H)-Benzofuranone, 5,6,7,7a-tetrahydro- (7.0\%), and phytol (1.44\%) as the major phytocompounds in the purified fraction of Maytenus senegalensis (Lam.) Exell. Other compounds identified in minute amounts include n-Hexadecanoic acid (0.207\%), 9,12-Octadecadienoic acid, methyl ester (1.67\%), cis-Vaccenic acid (0.4.90\%), 6-Methyl-cyclodec-5-enol (0.66\%) each with different biological activities (Table 6).

\section{Discussion}

The anti-plasmodial potency of some plants has been associated with the presence of some secondary metabolites such as alkaloids [9]. Findings presented in Table 3 shows that the purified fraction of $M$. senegalensis demonstrated a good antimalarial activities, in concordance with the classification of Munoz et al. [22], which stated that the antiplasmodial agent are classified on the basis of the percentages parasite inhibition as moderate", "good", and "very good when there is percentage inhibition of above $50 \%$ at metabolite concentration of 500, 250 and $100 \mathrm{mg} / \mathrm{kg}$ bwt. However, the antiplasmodial effects of the purified fraction at 150 and $300 \mathrm{mg} / \mathrm{kg}$ bw not significantly difference $(p>0.05)$, this may suggest that the maximum anti malaria effect of the purified fraction was achieved at $150 \mathrm{mg} / \mathrm{kg}$. The proposed mechanism of antiplasmodial effect of the purified fraction could be by the elevation of erythrocytes oxidation and inhibition of the plasmodium protein synthesis, a mechanism that has been attributed to antimalaria activities of some phytoconstituents [23].

Evidence for the anti-inflammatory properties of flavonoids and alkaloids have been reported by several studies using different models of inflammation [2426]. The significant anti-inflammatory effects demonstrated by the purified fraction of $M$. senegalensis leaf could be mechanistically explained by the fact that phyochemicals are known to inhibit the enzymes involved in the production of inflammatory mediator including cyclooxygenase and 5-lipoxygenase pathways [27].

Table 2 Antiplasmodial activity of purified fraction of M. senegalensis leaf against Plasmodium berghei Infected mice

\begin{tabular}{llllllllll}
\hline & Doses $(\mathrm{mg} / \mathrm{kg} \mathrm{bw})$ & 1 & 2 & 3 & 4 & 5 & 6 & Mean Parasitaemia & \% suppression \\
\hline MS & 75 & 60.36 & 66.25 & 70.25 & 64.25 & 65.25 & 78.25 & $67.83 \pm 5.43$ & $44.25 \pm 3.21^{\mathrm{a}}$ \\
& 150 & 28.25 & 34.05 & 36.25 & 29.05 & 34.05 & 38.25 & $33.17 \pm 3.45$ & $72.74 \pm 6.54^{\mathrm{b}}$ \\
& 300 & 30.05 & 34.05 & 25.05 & 26.25 & 32.25 & 26.05 & $26.83 \pm 2.90$ & $76.30 \pm 8.32^{\mathrm{b}}$ \\
$\mathrm{CQ}$ & 5 & 15.05 & 18.36 & 26.25 & 31.25 & 16.25 & 20.05 & $21.05 \pm 3.45$ & $82.74 \pm 7.56^{\mathrm{c}}$ \\
$\mathrm{NS}$ & $2 \mathrm{ml} / \mathrm{kg}$ & 122.05 & 120.07 & 115 & 116.25 & 131.25 & 126.67 & $121.67 \pm 7.54$ & \\
\hline
\end{tabular}

Data are MEAN \pm SEM of triplicate determinations. Values followed by different superscript are significantly different $(p<0.05)$

MS: Maytenus senegalensis (Lam.) Exell

CQ: Chloroquine

NS: Normal saline 
Table 3 Effect of purified fraction of $M$. senegalensis leaf on oedema

\begin{tabular}{llllllllll}
\hline Extract & Doses $(\mathrm{mg} / \mathrm{kg} \mathrm{bw})$ & 20 & 40 & 60 & 80 & 100 & 120 & Mean & Inhibition (\%) \\
\hline MS & 75 & $0.32 \pm 0.05$ & $0.38 \pm 0.02$ & $0.38 \pm 0.03$ & $0.36 \pm 0.02$ & $0.38 \pm 0.04$ & $0.38 \pm 0.04$ & $0.37 \pm 0.04$ & $53.16 \pm 4.09^{\mathrm{a}}$ \\
MS & 150 & $0.30 \pm 0.03$ & $0.36 \pm 0.04$ & $0.34 \pm 0.02$ & $0.30 \pm 0.06$ & $0.28 \pm 0.03$ & $0.30 \pm 0.02$ & $0.31 \pm 0.02$ & $60.76 \pm 7.54 \mathrm{~b}$ \\
ASA & 150 & $0.30 \pm 0.02$ & $0.30 \pm 0.02$ & $0.26 \pm 0.04$ & $0.28 \pm 0.02$ & $0.32 \pm 0.02$ & $0.30 \pm 0.03$ & $0.29 \pm 0.06$ & $63.29 \pm 5.98 \mathrm{~b}$ \\
NS & $2 \mathrm{~mL} / \mathrm{kg}$ & $0.80 \pm 0.04$ & $0.80 \pm 0.03$ & $0.76 \pm 0.05$ & $0.78 \pm 0.03$ & $0.82 \pm 0.05$ & $0.80 \pm 0.05$ & $0.79 \pm 0.03$ & \\
\hline
\end{tabular}

Data are MEAN \pm SEM of triplicate determinations. Values followed by different superscript are significantly different $(p<0.05)$ MS: Maytenus senegalensis (Lam.) Exell

ASA: Acetylsalicylic acid

NS: Normal saline

The present study revealed that the purified fraction of $M$. senegalensis leaf significantly decreased the acetic acid induced pain in mice. This study showed that the purified fraction of $M$. senegalensis leaf contains active analgesic component [28]. This finding is in concordance with previous studies on morphine alkaloid fraction of Stephia glabra known as Gindarudine, which showed significant analgesic effect when tested by the same method [29]. The significant analgesic and anti-inflammatory effects of the purified fractions of $M$. senegalensis leaf extracts in vivo is noteworthy. Plants with these added pharmacological phenomena in conjunction with antiplasmodial effects are better antimalarials than plants with the later potential only [30, 31].

Biochemical parameters have been widely used as an indicator of pathological condition, toxicology or safety of a test substance, treatment outcome and general health status of animals [32-35]. Among these biochemical parameters, transaminases, alkaline phosphatases, proteins, lipid profile and electrolyte are the most widely employed in assessing the liver and kidney integrity following plant extract administration to animals [33]. Alterations in the normal activities or concentrations of these biochemical parameters are conventional indicators of any of the following conditions; renal or nephrotic impairments, hepatocellular injury, cellular leakage, loss of functional integrity of cell membrane, biliary cirrhosis or liver hepatitis [32]. Consequently, the concentrations of triglyceride, sodium, potassium, chloride, alkaline phosphatase and glucose concentrations were not significantly $(p<0.05)$ altered by treatment with 75 and $150 \mathrm{mg} / \mathrm{kg}$ bw $M$ senegalensis purified fraction. This is an indication that the functional integrity of kidney is well preserved and that the purified fraction of $M$. senegalensis does not induced any form of pathological conditions to the kidney. The increases in transaminases (aspartate transaminase and alanine transaminase), and proteins concentration is an indication that the liver integrity is not well preserved. The purified fraction might have interfered with the equilibrium in protein metabolism in favor of anabolism. Such drastic increase in protein levels could, negatively affect cellular homeostasis and consequently effect the health of the animals [36, 37].

GCMS analysis of the purified fraction confirmed the

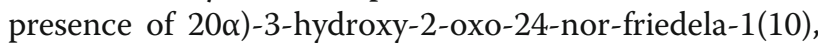
3,5,7-tetraen-carboxylic acid-(29)-methylester, 2(4H)Benzofuranone, 5,6,7,7a-tetrahydro, 3-hydroxy-20(29)lupen-28-ol and a terpenes (phytol) as the major constituents of the fraction. The antimalarial activities of these compounds have been previously documented, in addition phytol have also been reported for antiinflammatory activities.

\section{Conclusion}

The purified fraction of $M$. senegalensis leaf exhibited promising antimalarial, analgesic and anti-inflammatory activities. Thus, could serve as a template for the synthesis of new drug.

Table 4 Effect of purified fraction of $M$. senegalensis leaf on abdominal constrictions in mice

\begin{tabular}{lllllllll}
\hline Extract & Doses $(\mathrm{mg} / \mathrm{kg} \mathrm{bw})$ & \multicolumn{1}{c}{} & & Mean & Inhibition (\%) \\
\hline MS & 75 & $20.50 \pm 1.98$ & $20.56 \pm 1.07$ & $26.50 \pm 2.87$ & $21.05 \pm 1.08$ & $28.56 \pm 3.78$ & $23.00 \pm 1.89$ & $43.35 \pm 4.98^{\mathrm{a}}$ \\
MS & 150 & $19.55 \pm 0.98$ & $22.51 \pm 2.87$ & $18.56 \pm 1.09$ & $26.55 \pm 0.89$ & $27.56 \pm 4.87$ & $22.40 \pm 0.97$ & $44.83 \pm 3.86^{\mathrm{a}}$ \\
SD & 150 & $9.00 \pm 0.25$ & $8.56 \pm 1.09$ & $11.05 \pm 0.05$ & $10.21 \pm 0.56$ & $13.32 \pm 0.99$ & $10.20 \pm 0.78$ & $74.88 \pm 6.87^{\mathrm{b}}$ \\
NS & $2 \mathrm{~mL} / \mathrm{kg}$ & $36.50 \pm 3.89$ & $38.55 \pm 4.86$ & $42.55 \pm 387$ & $40.06 \pm 4.89$ & $47.50 \pm 6.07$ & $40.65 \pm 8.09$ & \\
\hline
\end{tabular}

Data are MEAN \pm SEM of triplicate determinations. Values followed by different superscript are significantly different $(p<0.05)$

SD: sodium diclofenac

MS: Maytenus senegalensis (Lam.) Exell

NS: Normal saline 
Table 5 Effect of purified fraction of $M$. senegalensis leaf on biochemical parameters in mice

\begin{tabular}{|c|c|c|c|}
\hline & $\begin{array}{l}\text { Control (normal } \\
\text { saline) }\end{array}$ & 75 mg/kg bw & $\begin{array}{l}150 \mathrm{mg} / \mathrm{kg} \\
\mathrm{bw}\end{array}$ \\
\hline Weight (g) & $26.51 \pm 0.78^{a}$ & $27.85 \pm 1.23^{a}$ & $28.23 \pm 0.98^{a}$ \\
\hline $\begin{array}{l}\text { Glucose (mg/ } \\
\mathrm{dL} \text { ) }\end{array}$ & $107.64 \pm 2.90^{\mathrm{a}}$ & $\underset{a}{109.03} \pm 3.87$ & $\underset{a}{117.36} \pm 5.98$ \\
\hline Tag & $170.97 \pm 3.89^{a}$ & $\underset{a}{170.93} \pm 5.98$ & $\underset{a}{173.70} \pm 7.09$ \\
\hline Prot (g/dL) & $4.66 \pm 0.04^{a}$ & $5.20 \pm 0.13^{b}$ & $5.41 \pm 0.43^{b}$ \\
\hline SGOT & $9.50 \pm 0.67^{a}$ & $13.50 \pm 1.03^{b}$ & $21.75 \pm 2.98^{c}$ \\
\hline SGPT & $6.25 \pm 0.56^{a}$ & $11.00 \pm 0.76^{b}$ & $18.00 \pm 0.65^{c}$ \\
\hline ALP & $34.5 \pm 2.90^{\mathrm{a}}$ & $37.25 \pm 2.90^{a}$ & $36.09 \pm 3.98^{a}$ \\
\hline Sodium & $134 \pm 5.09^{a}$ & $132.5 \pm 7.97^{a}$ & $\underset{a}{135.97} \pm 9.67$ \\
\hline Potassium & $3.35 \pm 0.54^{a}$ & $3.60 \pm 0.43^{a}$ & $3.24 \pm 0.21^{a}$ \\
\hline Chloride & $101.5 \pm 6.98^{a}$ & $\underset{a}{103.25 \pm 4.89}$ & ${\underset{a}{a}}_{a} 08.78 \pm 5.89$ \\
\hline
\end{tabular}

Data are Mean \pm SEM of triplicate determination. Value followed by different superscript alphabet along the row were significantly different $(p<0.05)$
Table 6 Phyto-Components identified in the purified fraction of Maytenus senegalensis (Lam.) Exell

\begin{tabular}{|c|c|c|c|c|}
\hline$\overline{\text { Peak\# }}$ & $\begin{array}{l}\text { Retention } \\
\text { Time }\end{array}$ & $\begin{array}{l}\text { Peak } \\
\text { Area\% }\end{array}$ & $\begin{array}{l}\text { Height } \\
\%\end{array}$ & Compound Name \\
\hline$\overline{1}$ & 13.624 & 0.13 & 0.26 & Dodecanoic acid, methyl ester \\
\hline 2 & 13.953 & 7.0 & 0.33 & $\begin{array}{l}\text { 2(4H)-Benzofuranone, 5,6,7,7a- } \\
\text { tetrahydro- }\end{array}$ \\
\hline 3 & 15.379 & 6.0 & 0.31 & $\begin{array}{l}\text { 20a)-3-hydroxy-2-oxo-24-nor- } \\
\text { friedela-1 (10),3,5,7-tetraen- } \\
\text { carboxylic acid-(29)-methylester }\end{array}$ \\
\hline 4 & 16.031 & 0.66 & 0.89 & 6-Methyl-cyclodec-5-enol \\
\hline 5 & 16.227 & 0.38 & 0.50 & $\begin{array}{l}\text { 3,7,11,15-Tetramethyl-2-hexadecen- } \\
\text { 1-ol }\end{array}$ \\
\hline 6 & 17.197 & 0.207 & 14.07 & n-Hexadecanoic acid \\
\hline 7 & 17.992 & 1.67 & 3.13 & $\begin{array}{l}\text { 9,12-Octadecadienoic acid, methyl } \\
\text { ester }\end{array}$ \\
\hline 8 & 18.101 & 1.44 & 2.43 & Phytol \\
\hline 9 & 18.170 & 1.52 & 2.80 & Methyl stearate \\
\hline 10 & 18.355 & 0.490 & 17.94 & cis-Vaccenic acid \\
\hline 11 & 20.336 & 0.47 & 0.79 & 2-methyltetracosane \\
\hline 12 & 21.095 & 12.95 & 16.42 & 3-hydroxy-20 (29)-lupen-28-ol \\
\hline 13 & 21.493 & 0.88 & 1.33 & d-Xylose, diheptyl mercaptal \\
\hline
\end{tabular}

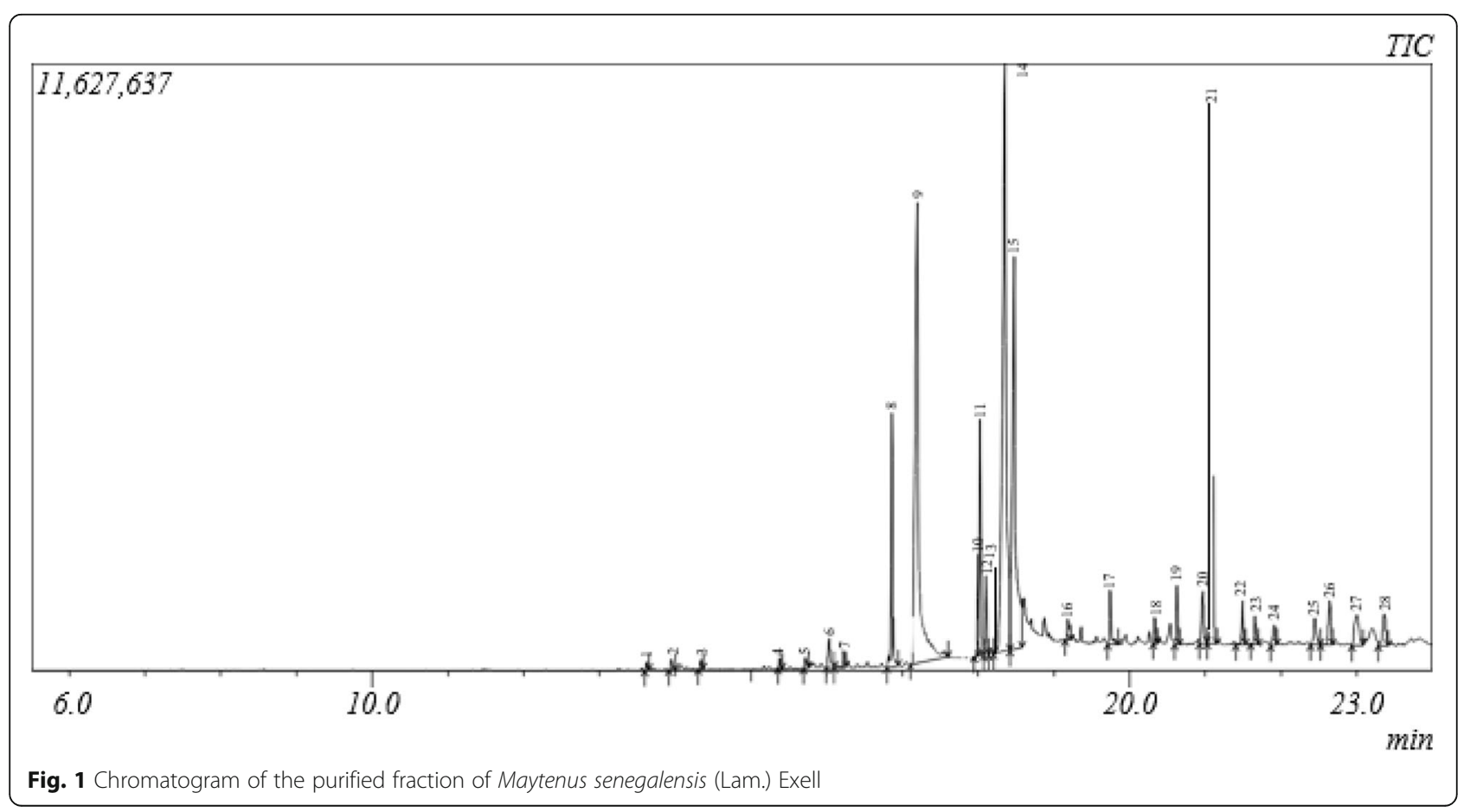




\section{Acknowledgements}

The authors appreciate the funding support of Tertiary Educational Fund of Nigeria and Federal University of Technology Minna.

\section{Conflict of interest}

The authors declared no conflict of interest exist.

\section{Authors' contributions}

This work is a collaboration of all the authors. All authors read and approved the final manuscript.

\section{Funding}

This research is supported by Research grant to Prof Ali Audu Jigam et al. 2019 (TETFUND/FUTMINNA/2016-2017/6TH BRP/17).

\section{Availability of data and materials}

All data are available in the manuscript.

\section{Ethics approval and consent to participate}

The principles governing the use of laboratory animals as laid out by the Federal University of Technology, Minna Committee on Ethics for Medical and Scientific Research and also existing internationally accepted principles for laboratory animal use and care as contained in the Canadian Council on Animal Care Guidelines and Protocol Review were duly observed.

\section{Consent for publication}

Not applicable.

\section{Competing interests}

The authors declare that they have no competing interests.

\section{Received: 8 November 2019 Accepted: 6 August 2020}

\section{Published online: 14 August 2020}

\section{References}

1. Odeghe OB, Uwakwe AA, Monago CC. Antiplasmodial activity of Methanolic stem bark extract of Anthocleista grandiflorain mice. Intern J Appl Sci Technol. 2012;24:18-23.

2. World Health Organization This year's malaria report at glance. "World Malaria Report (19 November 2018) World Health Organization 2018.

3. Greenwood BM, Fidock DA, Kyle DE, Kappe SHI, Alonso PL, Collins FH, Duffy PE. Malaria: progress perils and prospects for eradication. J Clin Invest. 2008; 118:1266-76.

4. Lawal B, Shittu Ok, Abubakar A, Kabiru AY. Human Genetic Markers and Structural Prediction of Plasmodium falciparum Multi-Drug Resistance Gene Pfmdr1 For Ligand Binding in Pregnant Women Attending General Hospital Minna. J Enviro public health. 2018; 1-13.

5. Mohiuddin M, Dewan SMD, Asarwar SM. Anti-nociceptive anti-inflammatory and antipyretic activities of Ethanolic extract of Atylosia scarabaeoides L. Benth family: Fabaceae leaves in experimental animal. J Appl Life Sci Inter. 2018:174:1-12.

6. Jigam AA, Mahmood F, Lawal B. Protective effects of crude and alkaloidal extracts of Tamarindus indica against acute inflammation and nociception in rats. J Acute Dis. 2017;62:78-81

7. Mostafa M, Appidi JR, Yakubu MT, Afolayan AJ. Anti-inflammatory antinociceptive and antipyretic properties of the aqueous extract of Clematis brachiata leaf in male rats. Pharm Biol. 2010:486-92.

8. Bashir L, Shittu OK, Sani S, Busari MB, Adeniyi KA. African natural products with potential Antitrypanosoma properties: a review. Inter J Bioch Res Rev. 2015;72:45-79

9. Lawal B, Shittu OK, Kabiru AY, Jigam AA, Umar MB. Berinyuy EB, Alozieuwa BU. Potential antimalarials from African natural products: a review. J Intercult Ethnopharmacol 2015; 44:318-343.

10. Lawal B, Shittu OK, Oibiokpa Fl, Berinyuy EB, Muhammed H. African natural products with potential antioxidants and hepatoprotectives properties: a review. Clin Phytosci 2017; 2, 23. https://doi.org/10.1186/s40816-016-0037-0.

11. Da Silva G, Serrano R, Silva O. Maytenus heterophylla and Maytenus senegalensis (lam.) Exell two traditional herbal medicines. J Nat Sc Biol Med. 2011;2:59-65.
12. El Tahir A, Ibrahim AM, Satti GM, Theander TG, Kharazmi A, Khalid SA. The potential antileishmanial activity of some Sudanese medicinal plants. Phytother Res. 2014;12:576-9.

13. Babiker F, Jamal P, Mirghani MES, Ansari AH. Characterization, purification and identification of some alkaloids in Datura stramonium. Inter Food Res J. 2017:24:540-3.

14. Jigam AA, Abdulrazaq UT, Egbuta MN. In-vivo antimalarial and toxicological evaluation of Chrozophoras enegalensis A. Juss euphorbiaceae extracts. J Appl Pharma Sci. 2011:110:90-4

15. Winter CA, Risley EA, Nuss GV. Carrageenin induced oedema in hindpaw of rats as an assay for anti-inflammatory drugs. Proc Soc for Exp Biol Med. 1962;3:544-7.

16. Nwafor PA, Nwajiobi N, Uko IE, Obot JS. Analgesic and anti- inflammatory activities of an ethanol extract of Smilax krausiana leaf in mice. Afr J Biomed Res. 2010:13:141-8.

17. Shittu OK, Lawal B, Alozieuwa BU, Haruna GM, Abubakar AN, Berinyuy EB. Alteration in biochemical indices following chronic administration of methanolic extract of Nigeria bee propolis in Wister rats. Asian Pac J Trop Dis. 2015:5(8):654-7.

18. Reitman S, Frankel S. A colorimetric method for the determination of serum glutamic oxalacetic and glutamic pyruvic transaminases. Am J Clin Pathol. 1957;28:56-63.

19. Gornall AC, Bardawill CJ, David MM. Determination of serum protein by means of biuret reaction. J Biol Chem. 1949;177:751-66.

20. Tietz NW. Clinical guide to laboratory tests. 3rd ed. Philadelphia, PA: WB Saunders Company; 1995. p. 286-8.

21. Patil A, Jadhav V. GC-MS analysis of bioactive components from methanol leaf extract of Toddalia asiatica (L). Inter J Pharm Sci Rev Res. 2014;29:18-20.

22. Muñoz V, Sauvain M, Bourdy G, Callapa J, Bergeron S, Rojas I. A search for natural bioactive compounds in Bolivia through a multidisciplinary approach, part I. evaluation of the antimalarial activity of plants used by the Chacobo Indians. J Ethnopharmacol. 2000;69:139-55

23. Pérez-Amador MC, Muñoz-Ocotero V, García JM, Castañeda AR, González E. Alkaloids in Solanum torvum Sw Solanaceae. Intern Exp Bot 2017;76:39-45.

24. Lamikanra AA, Theron M, Kooij TWA, Roberts DJ. Hemozoin malarial pigment directly promotes apoptosis of erythroid precursors. PLOS One. 2009:412:e8446.

25. Capra C. Anti-inflammatory activity of the saponins from Ruscus aculeatus. Fitoterapia. 2009;43(4):99-113.

26. Adesina DA, Adefolalu SF, Jigam AA, Lawal B. Antiplasmodial effect and sub-acute toxicity of alkaloid, flavonoid and phenolic extracts of Sida acuta leaf on Plasmodium berghei-infected animals. J Taibah Univ Sci. 2020;14(1): 943-53.

27. Chandel RS, Rastogi RP. Review: Triterpenoid Saponins and Sapogenins. Phytochem. 2012:19:1889-908.

28. Singh GB, Singh S, Bani S, Gupta BD, Banerjee SK. Anti-inflammatory activities of Oleanolic acid in rats and mice. J Pharm Pharmacol. 2012:445: 456-8.

29. Adebayo AH, John-Africa LB, Agbafor AG, Omotosho OE, Mosaku TO. Antinociceptive and anti-inflammatory activities of extract of Anchomanes difformis in rats. Pak J Pharm Sci. 2014:27(2):265-70.

30. Turner RA. Screening methods in Pharmacology. Vol 1. New York: Academic Press. 2014:85-106.

31. Semwal DK, Semwal RB, Semwal R, Jacob V, Singh G. Analgesic and antipyretic activities of gindarudine a morphine alkaloid from Stephania glabra. Curr Bio Comp. 2011;7:214-7.

32. Pascual ME, Slowing K, Caretero E, Mara K, Villar D. A. Lippia, traditional uses, chemistry and pharmacology. A Review J Ethnopharmacol. 2001; 76:201-14.

33. Yusuf AA, Lawal B, Abubakar AN, Berinyuy EB, Omonije YO, Umar SI, Shebe MN, Alhaji YM. In-vitro antioxidants, antimicrobial and toxicological evaluation of Nigerian Zingiber officinale. Clin Phytosci. 2018; 4: 12. https:// doi.org/10.1186/s40816-018-0070-2

34. Bashir L, Shittu OK, Busari MB, Sani S, Aisha MI. Safety evaluation of Giant African land snails (Archachatina marginata) Haemolymph on hematological and biochemical parameters of albino rats. J Adv Med Pharm Sci. 2015:3(3): 122-30

35. Umar SI, Ndako M, Jigam AA. Adefolalu SF, Ibikunle GF, Lawal B. Antiplasmodial, Anti-inflammatory, antinociceptive and safety profile of 
Maytenus senegalensis (Lam.) Exell root bark extract on hepato-renal integrity in experimental animals. Comp Clin Pathol. 2019;1-9. https://doi. org/10.1007/s00580-019-02965-4.

36. Yusuf AA, Lawal B, Yusuf MA, Omonije YO, Adejoke AA, Raji FH, Wenawo

DL. Free radical scavenging, antimicrobial activities and effect of sub-acute exposure to Nigerian Xylopia Aethiopica seed extract on liver and kidney functional indices of albino rat. Iran J Toxicol. 2018;12(3):51-8.

37. Lawal B, Shittu OK, Oibiokpa IF, Mohammed H, Umar SI, Haruna GM. Antimicrobial evaluation, acute and sub-acute toxicity studies of Allium sativum. J Acute Dis. 2016;5(4):296-301.

\section{Publisher's Note}

Springer Nature remains neutral with regard to jurisdictional claims in published maps and institutional affiliations.

\section{Submit your manuscript to a SpringerOpen ${ }^{\circ}$ journal and benefit from:}

- Convenient online submission

Rigorous peer review

- Open access: articles freely available online

High visibility within the field

- Retaining the copyright to your article

Submit your next manuscript at $\boldsymbol{\nabla}$ springeropen.com 